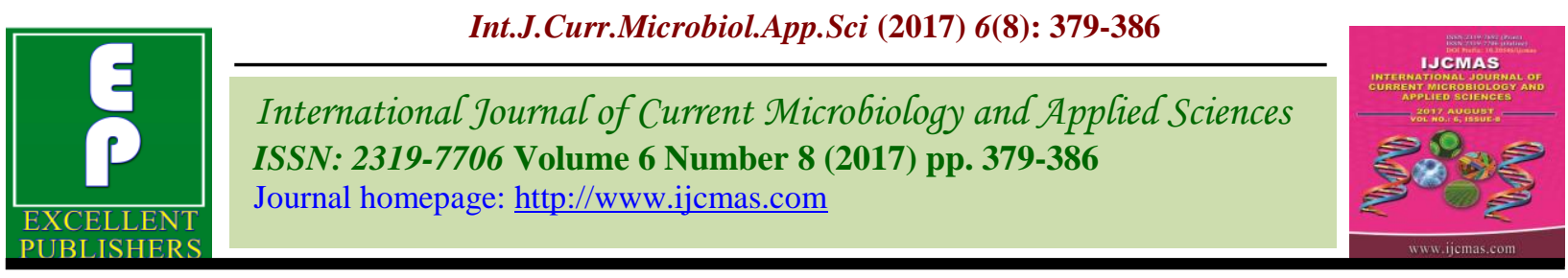

Original Research Article https://doi.org/10.20546/ijcmas.2017.608.051

\title{
Influence of Integrated Nutrient Management on Gladiolus (Gladiolus grandiflorus L.) cv. American Beauty
}

\author{
E. Sathyanarayana*, Sudha Patil, S.L. Chawla and Dishaben K. Patel \\ Department of Floriculture and Landscape Architecture, ASPEE College of Horticulture and \\ Forestry, Navsari Agricultural University, Navsari - 396 450, Gujarat, India \\ *Corresponding author
}

\begin{abstract}
A B S T R A C T
An investigation was carried out to study the influence of integrated nutrient management on flowering and corm parameters in gladiolus (Gladiolus grandiflorus L.) cv. American Beauty with the application of bio-fertilizers (Azotobacter, PSB and KMB), FYM and foliar spray of Nauroji Novel Organic Liquid Fertilizer with 100, 75 and 50\% recommended dose of NPK, respectively. The results showed that minimum days taken to spike initiation ( 48.10 days), maximum diameter of $2^{\text {nd }}$ floret $(8.50 \mathrm{~cm})$, number of florets per spike (11.30), number of spikes per plant (2.50), number of spikes per hectare (401234.57), number of corms per plant (2.43), weight of corms per plant $(76.00 \mathrm{~g})$, weight of cormels per plant $(12.67 \mathrm{~g})$, size of the corm $(5.67 \mathrm{~cm})$, nitrogen $(1.53 \%)$, phosphorus $(1.07 \%)$ and potash $(1.93 \%)$ contents in leaf, minimum soil electrical conductivity $\left(0.67 \mathrm{dSm}^{-1}\right)$ with highest available nitrogen $(178.73 \mathrm{~kg} / \mathrm{ha})$, available phosphorus $(19.48 \mathrm{~kg} / \mathrm{ha})$, available potash $(314.13 \mathrm{~kg} / \mathrm{ha})$, soil organic carbon $(0.80 \%)$ and microbial population $\left(90.67 \times 10^{-7} \mathrm{CFU} / \mathrm{g}\right.$ soil) was found with the application of $100 \%$ RDF + FYM @ 7.5 t/ha + Azotobacter + PSB + KMB + 1\% foliar spray of Nauroji Novel Organic Liquid Fertilizer $\left(\mathrm{T}_{10}\right)$.
\end{abstract}

\section{Introduction}

Gladiolus (Gladiolus grandiflorus L.) is one of the most popular ornamental bulbous plants grown in many parts of the world for its bewitching flowers. Internationally it is known for its dazzling florets colour, sturdy spike, size, attractive appearance and keeping quality which occupies fifth position in the international trade. It is native to South Africa and ranks second among the bulbous cut flowers in the Netherlands market. Popularity of this crop as a cut flower, it is grown throughout the world which is potential money spinner for floriculture industry with the production about 120 million spikes per year. To ensure maximization of productivity in any crop nitrogen, phosphorus and potassium are the three major nutrients that play very vital role in influencing vegetative growth, flower yield and quality attributes. However, considering the recent concept for eco-friendly technology, increased cost and timely non-availability of inorganic fertilizers, discriminate usage of chemicals leading towards poor soil fertility and soil health. In recent years, use of cost effective and ecofriendly bio-fertilizers and different organic sources in combination with inorganic fertilizers have resulted in increased 
production in many crops besides improving soil health and fertility levels along with that maintaining physical properties of soil and mobilization of nutrients. Similarly it is essential to evolve integrated nutrient management practices suitable for gladiolus crop.

Among various bio-fertilizers viz., Azotobacter, VAM (Vesicular arbuscular mycorryizae) and Trichoderma are important. Azotobacter is asymbiotic bacterium it lives in association with the host and fixes atmospheric nitrogen. The symbiotic association between fungi and root system of higher plants named as "Mycorrhiza". Biofertilizers have a supplementary nutritive role in productivity and by their usage; chemical fertilizers can be reduced to certain extent besides maintaining the soil fertility for a long time.

There is a need to standardize the different agro techniques and nutritional requirement through integrated nutrient management approach for improvement of productivity and spike quality of gladiolus. Field investigation was carried out to study the effect of integrated nutrient management on growth, quality and yield of gladiolus cv. American Beauty under open field conditions.

\section{Materials and Methods}

The experiment conducted at Floriculture Research Farm, Navsari Agricultural University, Navsari (Gujarat) and laid out in Randomized Block Design with ten treatments replicated thrice. Bio-fertilizers mixed with well decomposed farm yard manure and were applied treatment-wise at the time of planting and one per cent foliar spray of Nauroji Novel Organic Liquid Fertilizer at 40 days after planting of corms. Recommended fertilizer doses of 200: 200: $200 \mathrm{~kg} / \mathrm{ha}$ NPK were also given treatment- wise as 100, 75 and 50\%. These fertilizers were applied in the form of urea, single super phosphate and muriate of potash. Uniform size of gladiolus corms of cv. American Beauty was planted. The row to row distance of $30 \mathrm{~cm}$ and plant to plant distance of $20 \mathrm{~cm}$ in a plot size of $2.4 \times 1.6 \mathrm{~m}$. was maintained.

The treatments imposed were: $\mathrm{T}_{1}: 100 \%$ recommended dose of fertilizers, $\mathrm{T}_{2}: 50 \%$ $\mathrm{RDF}+\mathrm{FYM} @ 15 \mathrm{t} / \mathrm{ha}, \mathrm{T}_{3}: 75 \% \mathrm{RDF}+$ FYM @ 7.5 t/ha, T $: 100 \%$ RDF+FYM @ $7.5 \mathrm{t} / \mathrm{ha}, \mathrm{T}_{5}: 50 \% \mathrm{RDF}+\mathrm{FYM} @ 15 \mathrm{t} / \mathrm{ha}+$ Azotobacter + PSB + KMB, $\mathrm{T}_{6}: 75 \% \mathrm{RDF}+$ FYM @ 7.5 t/ha + Azotobacter + PSB + $\mathrm{KMB}, \mathrm{T}_{7}: 100 \% \mathrm{RDF}+\mathrm{FYM} @ 7.5 \mathrm{t} / \mathrm{ha}+$ Azotobacter $+\mathrm{PSB}+\mathrm{KMB}, \mathrm{T}_{8}: \mathrm{T}_{1}+$ Azotobacter $+\mathrm{PSB}+\mathrm{KMB}, \mathrm{T}_{9}: \mathrm{T}_{1}+1 \%$ foliar spray of Nauroji Novel Organic Liquid Fertilizer, $\mathrm{T}_{10}: \mathrm{T}_{7}+1 \%$ foliar spray of Nauroji Novel Organic Liquid Fertilizer. The observations on various flowering, corm yield characters and soil properties were recorded.

\section{Results and Discussion}

\section{Effect of INM on flowering parameters}

It is evident from table 1 that the integration of organic manures and bio-fertilizers with inorganic fertilizers showed significant response towards flower and corm yield attributes of gladiolus.

The results showed that minimum days taken to spike initiation (48.10 days), maximum diameter of $2^{\text {nd }}$ floret $(8.50 \mathrm{~cm})$, number of florets per spike (11.30), number of spikes per plant (2.50) and number of spikes per hectare (401234.57) were recorded under treatment $\mathrm{T}_{10}$ i.e. $\mathrm{T}_{7}+1 \%$ foliar spray of Nauroji Novel Organic Liquid Fertilizer followed by $\mathrm{T}_{7}$ i.e. 100\% RDF + FYM @ 7.5 t/ha + Azotobacter $+\mathrm{PSB}+\mathrm{KMB}$ and $\mathrm{T}_{6}$ i.e. $75 \% \mathrm{RDF}+\mathrm{FYM}$ @ $7.5 \mathrm{t} / \mathrm{ha}+$ Azotobacter + PSB + KMB, whereas minimum values of above mentioned 
parameters were recorded in treatments $\mathrm{T}_{1}$ (100\% RDF 200:200:200 NPK kg/ha). The significant increase in these parameters might be due to active and rapid multiplication of bacteria especially in rhizosphere creating favourable condition for nitrogen fixation and phosphorus solubilization at higher rate through nitrogen supply by nitrogenous fertilizers and supply of other nutrients, bacterial secretion, hormone production and supply of antibacterial and antifungal compounds, which were favourable for growth and ultimately increased yield. Nouroji novel organic liquid fertilizer contains growth promoting substances viz., GA, cytokinin and different micronutrients like $\mathrm{Fe}, \mathrm{Zn}, \mathrm{Mn}$ and $\mathrm{Cu}$.

These nutrients play a vital role on the growth and development of gladiolus plants, because of its stimulatory and catalytic effects on flower yield and metabolic processes. These findings corroborate with those of Yadav et al., (2005) in tuberose and Basoli et al., (2014) in gladiolus, Ali et al., (2013) in gladiolus and Sunitha et al., (2007) and Mittal et al., (2010) in marigold.

\section{Effect of INM on corm and cormel parameters}

Bio-fertilizers were found significant to affect corm characters in the present investigation. Significantly higher number of corms per plant (2.43), weight of corms per plant (76.00 $\mathrm{g})$, weight of cormels per plant $(12.67 \mathrm{~g})$ and size of the corm $(5.67 \mathrm{~cm})$ were registered with $\mathrm{T}_{10}\left(\mathrm{~T}_{7}+1 \%\right.$ foliar spray of Nauroji Novel Organic Liquid Fertilizer). Moreover, $\mathrm{T}_{7}$ i.e. $100 \% \mathrm{RDF}+\mathrm{FYM} @ 7.5 \mathrm{t} / \mathrm{ha}+$ Azotobacter + PSB + KMB and $\mathrm{T}_{6}$ i.e. $75 \%$ RDF+FYM @ 7.5 t/ha + Azotobacter+PSB $+\mathrm{KMB}$ found at par to $\mathrm{T}_{10}$ for corm and cormels characters. The use of bio-fertilizers increases number of microbes in soil which result into better root proliferation, more uptake of nutrients and water, luxuriant vegetative growth and more photosynthesis and enhanced food accumulation, enhanced capacity for absorption of ions and water from the soil resulting into increase in yield. The above results are in conformity with the finding of Kumari Vasantha et al., (2014) and Godse et al., (2006) in gladiolus.

Increase in average diameter and weight of corms and cormels due to application of biofertilizers might be due to fact that it increased nutrients availability to the plants, which increases photosynthetic activity of the plants and thereby, hastening the movement of photosynthetic sink towards the source (corm). Moreover, it also increases carbohydrates and auxin concentration in the roots resulting in thicker and well branched roots as observed by Srivastava and Govil (2005), Karthiresan and Venkatesha (2002) in gladiolus and Swaminathan et al., (1999) in tuberose. Phosphate solubilizing bacteria (PSB) are capable of increasing availability of phosphorus to plants either by mineralization of organic phosphate or by solubilization of inorganic phosphate by production of acids.

\section{Effect of INM on $N, P$ and $K$ contents in leaves}

The data presented in table 2 clearly indicate that the significantly highest nitrogen (1.53\%), phosphorus (1.07\%) and potash $(1.93 \%)$ in leaves of gladiolus. Were recorded with treatment $\mathrm{T}_{10}\left(\mathrm{~T}_{7}+1 \%\right.$ foliar spray of Nauroji Novel Organic Liquid Fertilizer). Similar results have also been reported by Ali et al., (2013) in gladiolus.

The combined application of organic, inorganic and bio-fertilizers significantly increased nitrogen content, which could be attributed to the rapid absorption of these elements by the plant surface and their translocation in the plant as reported by Singh et al., (2002) in gladiolus. 
Table.1 Effect of integrated nutrient management on flowering and corms parameters in gladiolus (Gladiolus grandiflorus L.) cv. American beauty

\begin{tabular}{|c|c|c|c|c|c|c|c|c|c|}
\hline Treatments & $\begin{array}{l}\text { Days to } \\
\text { spike } \\
\text { initiation }\end{array}$ & $\begin{array}{c}\text { Diameter } \\
\text { of } 2^{\text {nd }} \\
\text { floret } \\
(\mathrm{cm})\end{array}$ & $\begin{array}{l}\text { No. of } \\
\text { florets/ } \\
\text { spike }\end{array}$ & $\begin{array}{l}\text { Number of } \\
\text { spikes/plant }\end{array}$ & $\begin{array}{l}\text { No. of } \\
\text { spikes/ha }\end{array}$ & $\begin{array}{l}\text { No. of } \\
\text { corms/ } \\
\text { plant }\end{array}$ & $\begin{array}{l}\text { Weight of } \\
\text { corms/ } \\
\text { plant (g) }\end{array}$ & $\begin{array}{l}\text { Weight of } \\
\text { cormels/ } \\
\text { plant (g) }\end{array}$ & $\begin{array}{l}\text { Size of } \\
\operatorname{corm}(\mathrm{cm})\end{array}$ \\
\hline $\begin{array}{l}\mathrm{T}_{1}: 100 \% \text { RDF (200:200:200 NPK } \\
\mathrm{kg} / \mathrm{ha})\end{array}$ & 61.10 & 6.87 & 9.37 & 1.77 & 283950.62 & 1.73 & 53.33 & 8.37 & 4.20 \\
\hline $\mathrm{T}_{2}: 50 \% \mathrm{RDF}+\mathrm{FYM} @ 15 \mathrm{t} / \mathrm{ha}$ & 57.30 & 7.07 & 9.43 & 1.83 & 296296.30 & 1.80 & 54.67 & 8.40 & 4.40 \\
\hline $\mathrm{T}_{3}: 75 \% \mathrm{RDF}+\mathrm{FYM} @ 7.5 \mathrm{t} / \mathrm{ha}$ & 55.87 & 7.20 & 9.43 & 1.97 & 308641.98 & 1.90 & 55.33 & 9.83 & 4.51 \\
\hline $\mathrm{T}_{4}: 100 \% \mathrm{RDF}+\mathrm{FYM} @ 7.5 \mathrm{t} / \mathrm{ha}$ & 56.90 & 7.30 & 9.53 & 2.07 & 324074.07 & 1.97 & 59.00 & 9.87 & 4.63 \\
\hline $\begin{array}{l}\mathrm{T}_{5}: 50 \% \mathrm{RDF}+\mathrm{FYM} @ 15 \mathrm{t} / \mathrm{ha}+ \\
\text { Azotobacter + PSB + KMB }\end{array}$ & 56.53 & 7.40 & 9.87 & 2.13 & 341049.38 & 2.03 & 62.67 & 10.00 & 4.70 \\
\hline $\begin{array}{l}\mathrm{T}_{6}: 75 \% \mathrm{RDF}+\mathrm{FYM} @ 7.5 \mathrm{t} / \mathrm{ha}+ \\
\text { Azotobacter + PSB + KMB }\end{array}$ & 52.63 & 7.93 & 10.77 & 2.27 & 364197.53 & 2.17 & 65.33 & 10.77 & 5.00 \\
\hline $\begin{array}{l}\mathrm{T}_{7}: 100 \% \mathrm{RDF}+\mathrm{FYM} @ 7.5 \mathrm{t} / \mathrm{ha}+ \\
\text { Azotobacter + PSB + KMB }\end{array}$ & 51.67 & 7.63 & 10.30 & 2.40 & 370370.37 & 2.27 & 67.33 & 11.80 & 5.30 \\
\hline $\mathrm{T}_{8}: \mathrm{T}_{1}+$ Azotobacter $+\mathrm{PSB}+\mathrm{KMB}$ & 55.83 & 7.07 & 9.93 & 2.10 & 333333.33 & 2.07 & 62.00 & 10.33 & 4.60 \\
\hline $\begin{array}{l}\mathrm{T}_{9}: \mathrm{T}_{1}+1 \% \text { foliar spray of Nauroji } \\
\text { Novel Organic Liquid Fertilizer }\end{array}$ & 56.97 & 7.23 & 9.90 & 2.07 & 327160.49 & 2.00 & 61.33 & 9.87 & 4.40 \\
\hline $\begin{array}{l}\mathrm{T}_{10}: \mathrm{T}_{7}+1 \% \text { foliar spray of Nauroji } \\
\text { Novel Organic Liquid Fertilizer }\end{array}$ & 48.10 & 8.50 & 11.30 & 2.50 & 401234.57 & 2.43 & 76.00 & 12.67 & 5.67 \\
\hline S.Em \pm & 2.28 & 0.30 & 0.41 & 0.09 & 14326.85 & 0.10 & 4.24 & 0.68 & 0.27 \\
\hline C.D. at $5 \%$ & 6.77 & 0.90 & 1.20 & 0.27 & 42567.25 & 0.31 & 12.59 & 2.01 & 0.79 \\
\hline C.V.\% & 7.14 & 7.07 & 7.03 & 7.43 & 7.41 & 8.80 & 11.90 & 11.49 & 9.76 \\
\hline
\end{tabular}


Table.2 Effect of integrated nutrient management on N, P and K content in leaves and physic- chemical properties of soil in gladiolus (Gladiolus grandiflorus L.) cv. American beauty

\begin{tabular}{|c|c|c|c|c|c|c|c|c|c|}
\hline \multirow{2}{*}{ Treatments } & \multicolumn{3}{|c|}{$\begin{array}{c}\mathrm{N}, \mathrm{P} \text { and } \mathrm{K} \text { content in } \\
\text { Leaf }\end{array}$} & \multirow{2}{*}{$\begin{array}{c}\mathrm{EC} \\
\left(\mathrm{dSm}^{-1}\right)\end{array}$} & \multicolumn{3}{|c|}{ Available N, P and K in Soil } & \multirow{2}{*}{$\begin{array}{c}\text { Organic } \\
\text { carbon \% }\end{array}$} & \multirow{2}{*}{$\begin{array}{c}\text { Microbial population } \\
\text { (CFU/g Soil) } \\
\text { Colonies x } 10^{-7}\end{array}$} \\
\hline & $\mathbf{N \%}$ & $\mathbf{P \%}$ & $\mathbf{K} \%$ & & $\mathbf{N}(\mathrm{kg} / \mathrm{ha})$ & P (kg/ha) & K (kg/ha) & & \\
\hline $\begin{array}{l}\mathrm{T}_{1}: 100 \% \text { RDF }(200: 200: 200 \mathrm{NPK} \\
\mathrm{kg} / \mathrm{ha})\end{array}$ & 0.91 & 0.63 & 0.93 & 1.07 & 138.27 & 15.60 & 256.77 & 0.50 & 58.00 \\
\hline $\mathrm{T}_{2}: 50 \% \mathrm{RDF}+\mathrm{FYM} @ 15 \mathrm{t} / \mathrm{ha}$ & 1.03 & 0.67 & 0.83 & 1.03 & 151.00 & 16.77 & 259.00 & 0.60 & 61.67 \\
\hline $\mathrm{T}_{3}: 75 \% \mathrm{RDF}+\mathrm{FYM} @ 7.5 \mathrm{t} / \mathrm{ha}$ & 1.10 & 0.70 & 1.00 & 0.97 & 152.27 & 16.73 & 260.33 & 0.63 & 63.33 \\
\hline $\mathrm{T}_{4}: 100 \% \mathrm{RDF}+\mathrm{FYM} @ 7.5 \mathrm{t} / \mathrm{ha}$ & 1.13 & 0.73 & 1.43 & 0.90 & 152.83 & 15.07 & 268.00 & 0.67 & 65.00 \\
\hline $\begin{array}{l}\mathrm{T}_{5}: 50 \% \mathrm{RDF}+\mathrm{FYM} @ 15 \mathrm{t} / \mathrm{ha}+ \\
\text { Azotobacter + PSB + KMB }\end{array}$ & 1.20 & 0.77 & 1.40 & 0.83 & 157.00 & 16.70 & 270.90 & 0.70 & 69.00 \\
\hline $\begin{array}{l}\mathrm{T}_{6}: 75 \% \mathrm{RDF}+\mathrm{FYM} @ 7.5 \mathrm{t} / \mathrm{ha}+ \\
\text { Azotobacter + PSB + KMB }\end{array}$ & 1.27 & 0.83 & 1.67 & 0.73 & 165.70 & 17.27 & 304.67 & 0.63 & 79.00 \\
\hline $\begin{array}{l}\mathrm{T}_{7}: 100 \% \mathrm{RDF}+\mathrm{FYM} @ 7.5 \mathrm{t} / \mathrm{ha}+ \\
\text { Azotobacter + PSB + KMB }\end{array}$ & 1.33 & 0.87 & 1.83 & 0.80 & 167.85 & 18.94 & 307.00 & 0.73 & 82.67 \\
\hline $\mathrm{T}_{8}: \mathrm{T}_{1}+$ Azotobacter $+\mathrm{PSB}+\mathrm{KMB}$ & 1.07 & 0.72 & 1.63 & 0.90 & 155.53 & 17.00 & 272.33 & 0.60 & 73.67 \\
\hline $\begin{array}{l}\mathrm{T}_{9}: \mathrm{T}_{1}+1 \% \text { foliar spray of Nauroji } \\
\text { Novel Organic Liquid Fertilizer }\end{array}$ & 1.17 & 0.75 & 1.57 & 1.00 & 155.10 & 17.06 & 266.67 & 0.57 & 72.00 \\
\hline $\begin{array}{l}\mathrm{T}_{10}: \mathrm{T}_{7}+1 \% \text { foliar spray of Nauroji } \\
\text { Novel Organic Liquid Fertilizer }\end{array}$ & 1.53 & 1.07 & 1.93 & 0.67 & 178.73 & 19.48 & 314.13 & 0.80 & 90.67 \\
\hline S.Em \pm & 0.08 & 0.05 & 0.08 & 0.05 & 6.26 & 0.79 & 11.56 & 0.03 & 5.48 \\
\hline C.D. at $5 \%$ & 0.22 & 0.15 & 0.23 & 0.14 & 18.61 & 2.34 & 34.34 & 0.09 & 16.29 \\
\hline C.V.\% & 11.16 & 11.26 & 9.24 & 8.94 & 6.89 & 7.99 & 7.20 & 8.34 & 13.28 \\
\hline
\end{tabular}


The role of phosphate solubilizing bacteria increases the availability of phosphorus in soil through the secretion of phosphatase enzyme which leads to transfer organic phosphorus to their available forms and consequently, it enhances phosphorus absorption and accumulation in plant tissues reported in tuberose by Swaminathan et al., (1999). The increment in potassium percentage might be due to the effect of different strain groups and potassium mobilizing microorganisms. Moreover, by using Nouroji novel liquid organic fertilizer which contains potash in available form and also helps in availability of metals increased levels of extracted minerals.

\section{Effect of Integrated Nutrient Management (INM) on Physico- Chemical properties of soil}

Different combination of inorganic and biofertilizers had significantly affected physico chemical properties of soil (Table 2). The minimum soil electrical conductivity $(0.67$ $\left.\mathrm{dSm}^{-1}\right)$ and highest available nitrogen (178.73 $\mathrm{kg} / \mathrm{ha}$ ), available phosphorus (19.48 kg/ha), available potash $(314.13 \mathrm{~kg} / \mathrm{ha})$, soil organic carbon $(0.80 \%)$ and microbial population (90.67 x $10^{-7} \mathrm{CFU} / \mathrm{g}$ soil) were recorded in 100\% RDF + FYM @ 7.5 t/ha + Azotobacter $+\mathrm{PSB}+\mathrm{KMB}+1 \%$ foliar spray of Nauroji Novel Organic Liquid Fertilizer $\left(\mathrm{T}_{10}\right)$ followed by 100\% RDF + FYM @ 7.5 t/ha + Azotobacter + PSB + KMB $\left(\mathrm{T}_{7}\right)$ and $75 \%$ RDF + FYM @ 7.5 t/ha + Azotobacter + PSB $+\mathrm{KMB}\left(\mathrm{T}_{6}\right)$ whereas, minimum values was observed in treatment $\mathrm{T}_{1}(100 \% \quad \mathrm{RDF}$ 200:200:200 NPK kg/ha).

Higher availability of nitrogen in soil with the treatment of bio-fertilizers in combination with chemical fertilizer can be attributed to direct application of chemical fertilizers and release of nitrogen through biological fixation of atmospheric nitrogen by bacterial fertilizers like Azotobacter. The buildup of available phosphorus and potassium in the soil could be due to the organic acids which were released by increased microbial population in soil due to application of PSB and KSB. Application of chemical fertilizer also enhanced the nutrient availability in soil but at lower amount as compared to combined use of biofertilizers and chemical fertilizer. The lower values of available NPK in soil can be due to maximum utilization of applied nutrients by the crop, which were in the most available form. Godse et al., (2006) reported that combined application of bio-fertilizers, organic and inorganic fertilizers (Azotobacter $+\mathrm{PSB}+\mathrm{KMB}+\mathrm{FYM}+100 \% \mathrm{RDF})$ increased soil $\mathrm{N}, \mathrm{P}$ and $\mathrm{K}$ availability compared with inorganic fertilizers alone. Similar findings were also reported by Basoli et al., (2014) in gladiolus and Rajadurai et al., (2000) in marigold.

The organic carbon content of the soil was increased due to addition of nutrients through inorganic and organic sources caused a marked improvement in organic carbon content and thus on decomposition increased organic carbon in the soil. These findings are in conformity to that of Kanwar et al., (2002) and Sen (2003) who reported increase in soil organic carbon content with the treatments having organic manures in comparison to inorganic treatments.

Under the present investigations bio-fertilizer inoculation along with FYM significantly increased the microbial populations in the soil profile. However, a gradual decrease in biological properties of soil was noticed with the increase in NPK doses. Inorganic fertilizers supplied must have acted as food for the local population of microbes hence multiplied in large number and more count. But when inorganic fertilizers were supplied in heavy doses these must have caused toxicity to the local population of microbes due to feedback inhibition hence less 
microbial count was noticed with heavy fertilizer doses similar findings were reported by Subha Rao et al., (1993) Swarup et al., (2000) and Shashidhara and Gopinath (2002) in calendula.

So, it can be concluded that application of 100\% RDF + FYM @ 7.5 t/ha + Azotobacter $+\mathrm{PSB}+\mathrm{KMB}+1 \%$ foliar spray of Nauroji Novel Organic Liquid Fertilizer is most effective among various treatments in flowering and corms characters of gladiolus cv. American Beauty under South Gujarat condition. This also indicates the possibility of reducing the dose of chemical fertilizers, which is cost effective and eco-friendly for the cultivation.

\section{References}

Ali, A.; Mehmood, T.; Hussain, R.; Bashir, A.; Raza, S.; Din, N.U. and Ahmad, A. (2013). Investigation of bio-fertilizers influence on vegetative growth, flower quality, bulb yield and nutrient uptake in gladiolus (Gladiolus grandiflorus L.). Inter. J. Plant, Animal \& Environ. Sci., 4(1): 2231-4490.

Basoli, M., Kumar, P. and Kumar, S. (2014). Impact of integrated nutrient management on post-harvest and corm characters of gladiolus cv. Novalux Annals Hort., 7 (2): 109-114.

Godse, S. B.; Golliwar, V. J.; Bramhankar, K. S. and Kore, M. S. (2006). Effect of organic manures and bio-fertilizers with reduced doses of inorganic fertilizers on growth, yield and quality of gladiolus. J. Soils Crops, 16(2): 445-449.

Kanwar, K.; Paliyal, S. S.; Nandal, T. R. and Kanwar, K. (2002). Integrated nutrient management in cauliflower cv. Pusa Snowball K-1. Research on Crops, 3(3):579-583.

Karthiresan, C. and Venkatesha, J. (2002). Effect of bio-fertilizers with the levels of $\mathrm{N}$ and $\mathrm{P}$ on gladiolus. Floriculture research trend in India. Proceedings of National Symposium on Indian Floriculture in the New Millennium, Bangalore, pp. 118-121.

Kathiresan, C. and Venkatesha, J. (2002). Effect of bio-fertilizer with levels of $\mathrm{N}$ and $\mathrm{P}$ on gladiolus. In: Floriculture research trends in India. pp -118-121.

Kumari Vasantha, R.; Kumar, D. P.; Kumar, A. B. and Mahadevamma, M. (2014). Effect of integrated nutrient management on floral and cormel parameters in gladiolus (Gladiolus hybridus L.) cv. American Beauty. Inter. J. Agril. Sci., 10(1): 15-22.

Mittal, R.; Patel, H. C.; Nayee, D. D. and Sitapara, H. H. (2010). Effect of integrated nutrient management on growth and yield of African marigold (Tagetes erecta L.) cv. Local under middle Gujarat agro-climatic conditions. Asian J. Hort., 5(2): 347349.

Rajadurai, K. R.; Manivannan, K.; Jawaharlal, M. and Beaulah, A. (2000). Effect of Azospirillum and VAM on growth characters of African marigold (Tagetes erecta L.). South Indian Hort., 48(1-6): 83-87.

Sen, H. S. (2003). Problem soils in India and their management: Prospect and Retrospect. J. Indian Society Soil Sci. 51(4):388-408.

Shashidhara, G. R. and Gopinath, G. (2002). Effect of nutrients and bio-inoculants on calendula. In: Floriculture research trend in India-Proceedings of the national symposium on Indian floriculture in the new millennium, Bangalore, pp. 206-208.

Singh, W.; Sehrawat, S. K.; Dahiya, D. S. and Singh, K. (2002). Leaf nutrient status of gladiolus (Gladiolus grandiflorus L.) cv. Sylvia as affected by NPK application. Haryana J. Hort., 31(1-2): 
49-51.

Srivastava, R. and Govil, M. (2005). Influence of bio-fertilizers on growth and flowering in gladiolus cv. American Beauty. Acta Hort., 742: 456-462.

Subha Rao, N. S. (1993). Bio-fertilizers in Agriculture and Forestry. $3^{\text {rd }}$ Rev. Ed. Oxford Publishing Co. Ltd., New Delhi., pp.72-73.

Sunitha, H. M.; Ravi, H.; Vyakaranahal, B. S. and Bablad, H. B. (2007). Effect of plant spacing and integrated nutrient management on yield, quality of seed and vegetative growth paramrters in African marigold (Tagetes erecta L.). $J$. Ornam. Hort., 10(4): 245 -249.

Swaminathan, V., Ramaswamy, N. and Pillai, O. A. A. (1999). Effect of Azospirillum, phosphobacteria and inorganic nutrients on the growth and yield of tuberose. South Indian Hort., 47(1/6): 331-334.

Swarup, A., Manna, M. C. and Singh, G. B. (2000). Impact of land use and management practices on organic carbon dynamics in soils of India. In: Advances in Soil Sci. Global Climate Change \& Trop. Eco., (Lal. R et al., Eds). CRC/Lewis Publishers Boca Raton, FL (USA). pp. 261-281.

Yadav, B. S., Gupta, A. K. and Singh, S. (2005). Studies on the effect of nitrogen, plant spacing and biofertilizers on growth parameters in tuberose cv. Double. Haryana J. Hort., 34(1-2): 78-80.

\section{How to cite this article:}

Sathyanarayana, E., Sudha Patil, S.L. Chawla and Dishaben K. Patel. 2017. Influence of Integrated Nutrient Management on Gladiolus (Gladiolus Grandiflorus L.) cv. American Beauty. Int.J.Curr.Microbiol.App.Sci. 6(8): 379-386. doi: https://doi.org/10.20546/ijcmas.2017.608.051 